\title{
Long-Term Behaviour of Temperature in the Lower Atmosphere of Niamey a West African Tropical Station
}

\author{
Pétronille Kafando ${ }^{1 *}$, Bruno Korgo ${ }^{2}$, Madé Fodé ${ }^{3}$ \\ ${ }^{1}$ Laboratoire de Physique et de Chimie de l'Environnement, Université Joseph Ki-Zerbo, Ouagadougou, Burkina Faso \\ ${ }^{2}$ Laboratoire d'Energie Thermique et Renouvelable, Université Joseph Ki-Zerbo, Ouagadougou, Burkina Faso \\ ${ }^{3}$ Département de Physique, Faculté des Sciences et Techniques, Université Abdou Moumoumi, Niamey, Niger \\ Email: *kafandopetronille@yahoo.fr
}

How to cite this paper: Kafando, P., Korgo, B. and Fodé, M. (2021) Long-Term Behaviour of Temperature in the Lower Atmosphere of Niamey a West African Tropical Station. Atmospheric and Climate Sciences, 11, 165-176.

https://doi.org/10.4236/acs.2021.111011

Received: December 13, 2020

Accepted: January 22, 2021

Published: January 25, 2021

Copyright $\odot 2021$ by author(s) and Scientific Research Publishing Inc. This work is licensed under the Creative Commons Attribution International License (CC BY 4.0).

http://creativecommons.org/licenses/by/4.0/

\begin{abstract}
This paper highlights the global warming of the lower atmosphere of West African tropical area using in-situ data. The study is based on the analysis of 500-m interval vertical profiles of radiosonde temperature above Niamey $\left(13.47^{\circ} \mathrm{N} ; 2.16^{\circ} \mathrm{E}\right)$ a sub-Saharan meteorological station. The annual cycle of surface temperatures shows seasonally two peaks located in April/May and in October and two minimum in December/January and August respectively. In the mid-troposphere (between $5 \mathrm{~km}$ and $10 \mathrm{~km}$ height), time series of monthly mean temperatures from January 2001 to December 2018, shows an annual variability with a slight downward trend of $-0.036^{\circ} \mathrm{C}$ per decade. In the lower stratosphere $\left(25-30 \mathrm{~km}\right.$ altitude) a cooling of $-0.64^{\circ} \mathrm{C} /$ decade is observed. Temperatures time series also highlight the presence of two breaking points associated with the El Niño-Southern Oscillation (ENSO) events. When performing a separation regarding Southern Oscillation Index (SOI) time series, model parameters of the linear regression indicate a tropospheric warming during the neutral and La Niña phases and a stratospheric cooling. The analysis of the lower stratosphere zonal wind highlights different behaviours of the quasi-biennial oscillation (QBO) during the neutral and La Niña phases.
\end{abstract}

\section{Keywords}

Global Warming, West Africa, Tropical Troposphere, Tropical Lower Stratosphere, QBO, El Niño, La Niña

\section{Introduction}

The reality of global warming has been highlighted by measurements which in- 
dicate an increase in the global average temperature of around $0.2^{\circ} \mathrm{C}$ to $0.6^{\circ} \mathrm{C}$ since the end of the 19th century [1] [2] and impacting on climate variability. The Sahel located in West Africa in the band of latitudes between $12^{\circ} \mathrm{N}$ and $20^{\circ} \mathrm{N}$ by its key position between the Sahara desert and the humid regions of tropical Africa, is one of the regions of the world that experiences great climatic variability. This region is extremely vulnerable to changes in rainfall patterns which have a significant impact on agriculture, the main activity for about $80 \%$ of the population. Floods and/or droughts have a socio-economic influence with often disastrous consequences on water resources, agriculture, livestock, health, ... In this region, most of the studies on global warming and/or climate change and the associated impacts mostly focus on surface parameters such as temperature [3], precipitations [3] [4] [5], water resources [6] [7], vegetation cover [8], ... Climate projections using a wide range of models do not match much for West Africa, this discrepancy is partly due to the fact that climate models cannot capture the fundamental characteristics of the climate variability in the region [9]. Forecasts of precipitation, vegetation, clouds, greenhouse gases, ... from models are sometimes less efficient [10]; however all the climate models predict an increase in surface temperatures. Some differences exist regarding the values. Due to different physical processes involved in the atmospheric layers, the surface, the troposphere, and the stratosphere respond differently to climate forcings [1]. Some differences in atmospheric temperature trends from the surface to the lower stratosphere have been reported and discrepancies in the tropics still remain.

The present work aims at characterizing long-term evolution of temperature in West Africa's tropical troposphere and lower stratosphere. The study used meteorological radiosonde dataset above Niamey $\left(13.47^{\circ} \mathrm{N} ; 2.16^{\circ} \mathrm{E}\right)$ from January 2001 to December 2018. The followings describe the datasets and analyses in Section 2 and meteorological characteristics of Niamey in Section 3. Results are presented in Section 4, discussion is dealt in Section 5 and conclusion is set out in Section 6.

\section{Datasets and Analyses}

\subsection{Datasets}

- The first dataset is daily radiosonde (RS) data from Wyoming University database (at http://weather.uwyo.edu/upperair/sounding.html) for the period extending from January 2001 to December 2018. A total of 5401 vertical profiles of temperature are selected from 1200 UTC RS for the station of Niamey (Figure 1).

- The second dataset is monthly Southern Oscillation Index (SOI) from the National Oceanic and Atmospheric Administration's (NOAA) database (at https://www.ncdc.noaa.gov/teleconnections/enso/indicators/soi/) for the period January 2001 to December 2018. This index is used to measure the large-scale fluctuations in air pressure occurring during El Niño and La Niña episodes. Negative (positive) SOI values coincide with abnormally warm 
(cold) ocean waters across the eastern tropical Pacific typical of El Niño (La Niña) episodes (Figure 2).

- The third dataset consists of quasi-biennial oscillation (QBO) calculated at PSL (from the zonal average of the $30 \mathrm{mb}$ zonal wind at the equator as computed from the NCEP/NCAR Reanalysis) (at

https://psl.noaa.gov/data/correlation/qbo.data).

\subsection{Analyses}

Daily raw temperature profiles are re-sampled every $500 \mathrm{~m}$ using a cubic spline interpolation. Then the monthly mean temperature is calculated by averaging for each altitude level all the profiles in the month. This study focused on the analysis of tropospheric and lower stratospheric temperature: mid-troposphere (MT) ranging from $5 \mathrm{~km}$ to $10 \mathrm{~km}$ and upper troposphere (UT) between 10 and $15 \mathrm{~km}$, and lower stratosphere (LS) ranging from 25 to $30 \mathrm{~km}$.

Long time series of meteorological parameters are subject to many types of variability and this has led us to focus on the breaking points contained in datasets. Thus, MATLAB has been used to find the points where the mean or the slope of the series change most abruptly.

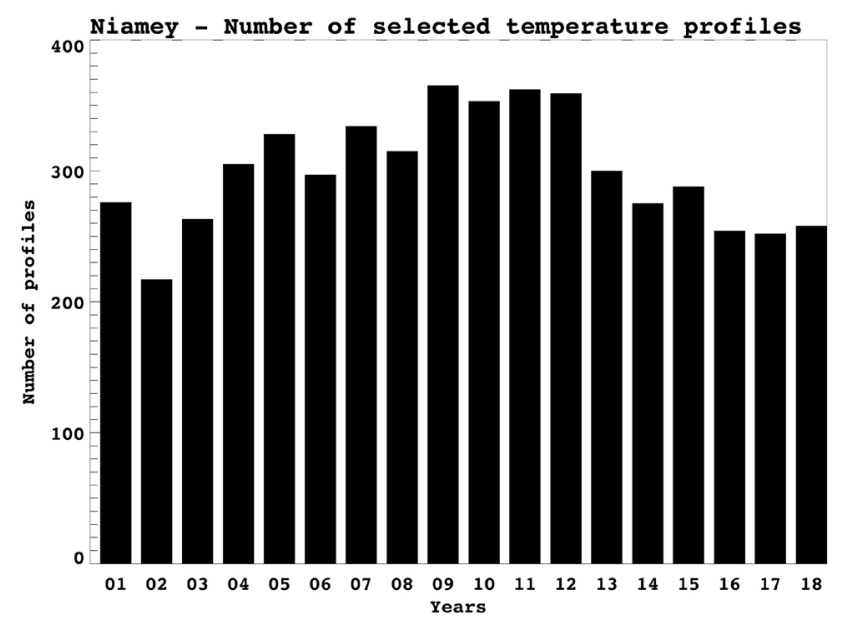

Figure 1. Histogram of number of selected profiles for Niamey from 2001 to 2018.

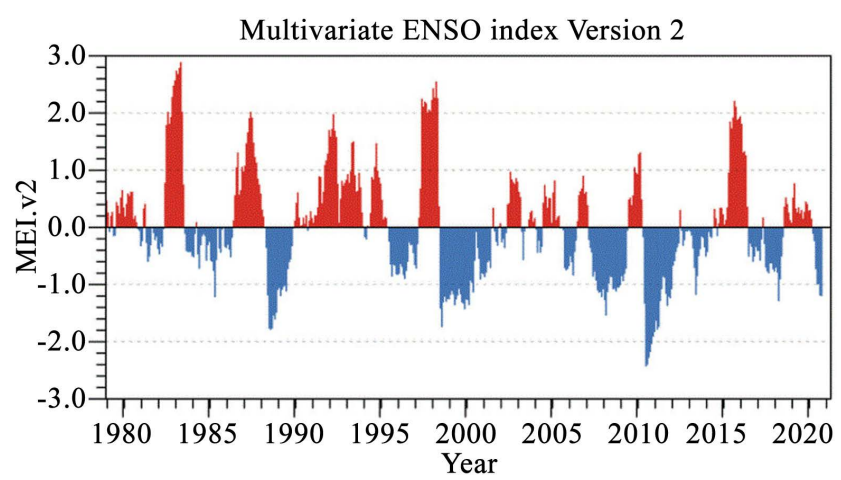

Figure 2. Multivariate ENSO index version 2 (MEI.v2) from 1979 to 2020. (Source: https://www.psl.noaa.gov/enso/mei/) 


\section{Meteorological Characteristics of Niamey}

Niamey $\left(13.47^{\circ} \mathrm{N} ; 2.16^{\circ} \mathrm{E}\right)$ is located in the south-western part of Niger (Figure 3) which is in central Sahel. The prevailing climate is a semi-arid tropical climate, with two main seasons determined by the latitudinal displacement of the intertropical convergence zone:

- A long dry season from October to April/May: this season is characterized by a North-Eastern dry and dusty wind coming from the Sahara desert and an absence of precipitation. High surface temperatures are greater than $40^{\circ} \mathrm{C}$.

- A rainy season from June to September: During this season at the surface and in the UT, prevailing winds are Southwesterly (a wet warm wind coming from the ocean) and westerly respectively. The annual total precipitation is around $750 \mathrm{~mm}$ and the heaviest daily precipitation usually occurs in July and August. Surface temperatures decrease because of precipitations which refresh the atmosphere.

The annual cycle of surface temperatures presents two seasonal maxima of temperatures that occur during the dry season in April/May and in October with temperatures over $40^{\circ} \mathrm{C}$ and two seasonal minima of $10^{\circ} \mathrm{C}$ and $20^{\circ} \mathrm{C}$, recorded respectively in December/January and in August. During the rainy season, temperatures generally reach their relative minimum in August and their relative maximum towards the end of the season (September and October) (Figure 4).

\section{Results}

Figure 5 presents the time series of monthly mean temperatures for the MT and the UT. In the MT an annual cycle appears with maximum values or around $-21^{\circ} \mathrm{C}$ located from November to February and minimum values of around $-18^{\circ} \mathrm{C}$ from May to August. From January 2016 to December 2018 erratic fluctuations appear probably due to lot of missing data. So the period ranging from January 2016 to December 2018 has been discarded from our study. The analysis

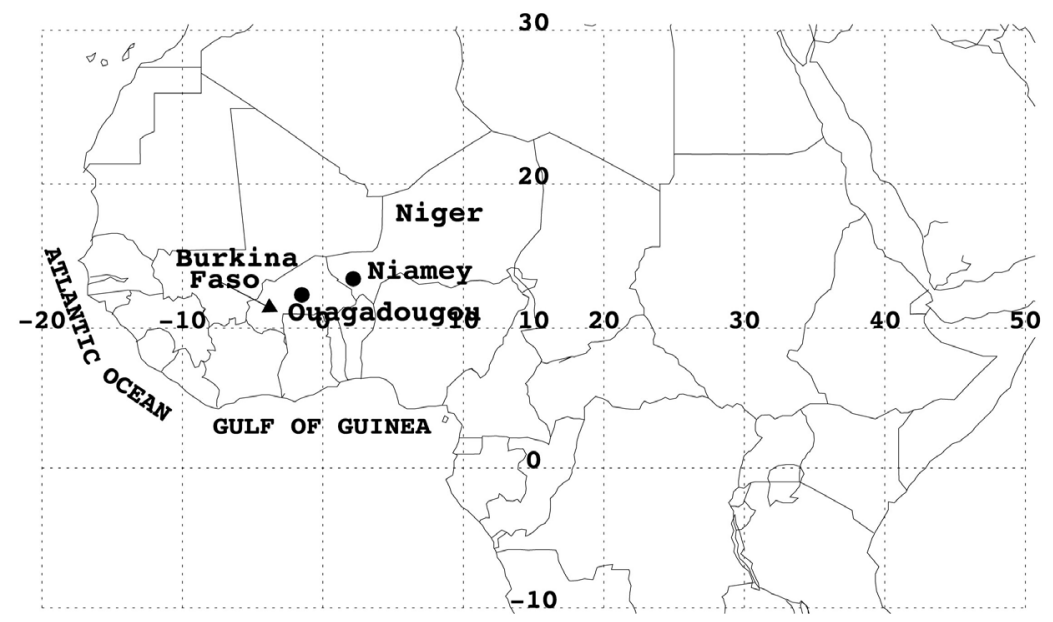

Figure 3. Location of Niamey and Ouagadougou meteorological stations. 


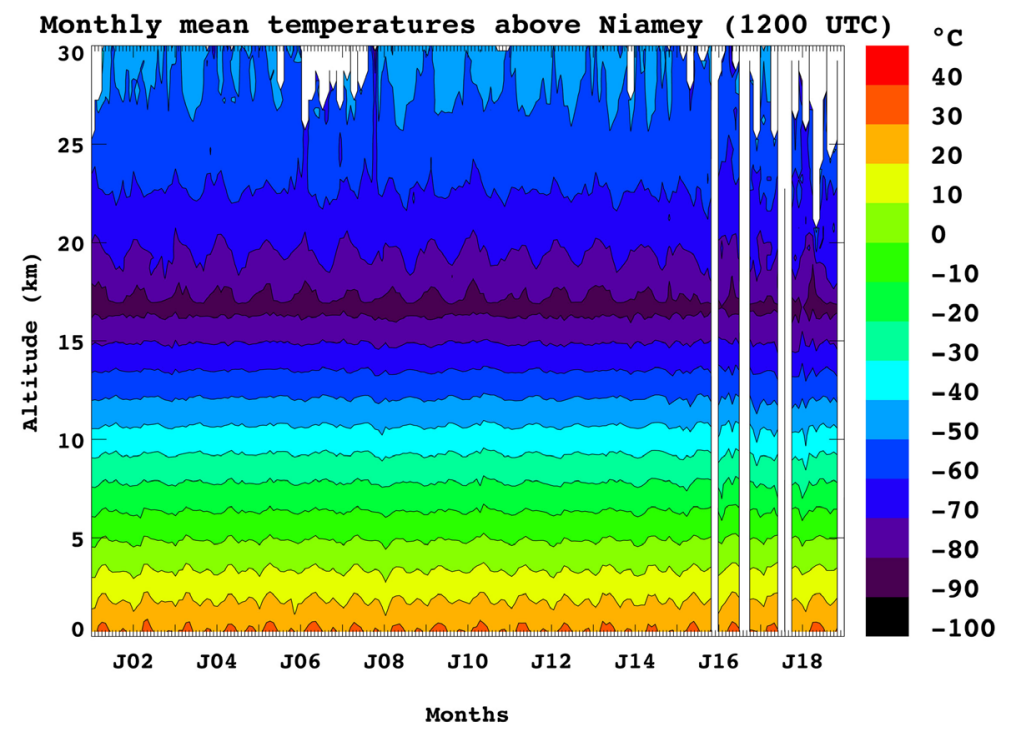

Figure 4. Time-altitude monthly average temperatures for 2001-2018 at 1200 UTC above Niamey.

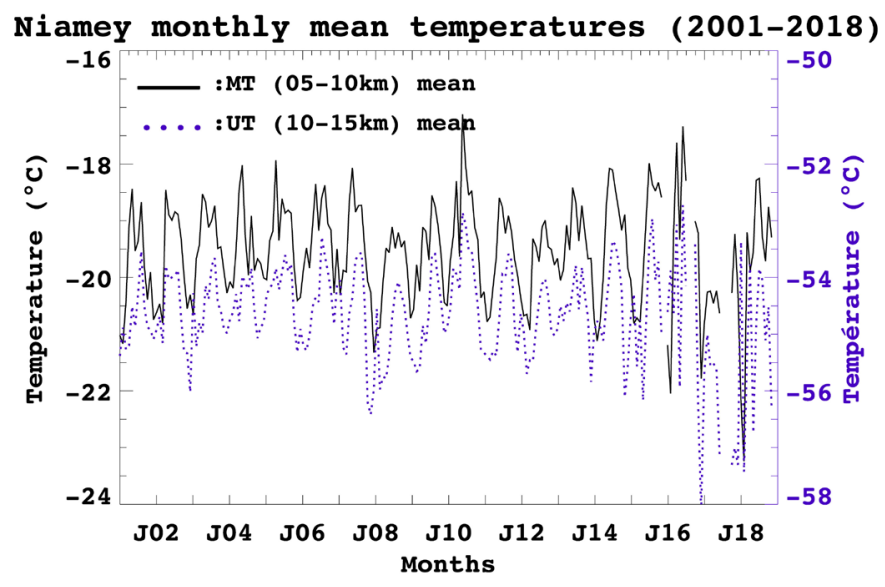

Figure 5. Monthly average temperatures from 2001 to 2018 in the MT (solid line, values on left hand ordinates) and in the UT (dotted line, values on right hand ordinates) above Niamey.

of UT monthly mean temperatures shows similar variation to MT ones with however maximum and minimum temperatures different from the lower level. These values are $-53^{\circ} \mathrm{C}$ and $-55^{\circ} \mathrm{C}$ for maximum and minimum temperatures respectively. The above descriptions showing a good agreement between the variations of mean temperatures in the two regions, our study will focus on the MT.

El Niño-Southern Oscillation (ENSO) is known to be one of the most prominent natural phenomena leading to interannual variability in several regions in the world [11] [12]. The warming of the eastern equatorial Pacific Ocean named as El Niño events are followed after a lag of around $4-6$ months by a warming of the troposphere in some regions [13]. We have performed an analysis consisting of the comparison of series trends in relation with ENSO to examine the 
influence of this signal on temperature above Niamey in the tropics (Figure 6). First, Figure 6(a) shows time series of monthly mean SOI for January 2001 to December 2018 period. One breaking point is detected separating the series in two intervals regarding the mean of SOI data. The first interval for which the mean value is nearly zero (mean SOI value of +0.06 ) characterizes a mild El Niño which can be associated to the neutral phase of ENSO. This neutral phase is observed from early 2001 to approximately the end of 2007. For the second interval, mean SOI value is +0.52 indicating La Niña event from early 2008 to the end of 2015. These two phases are consistent with Figure 2.

In Figure 6(b) regarding the change in the positive slope of the linear regression of monthly mean temperature time series, a breaking point is detected approximately at the same position of SOI series one. Thus the two temperature series highlighted can be nearly superimposed to the two SOI intervals. The two slopes are increasing and the warming rate is $+1.2^{\circ} \mathrm{C}$ per decade for both series. This rate decreases to $+0.062^{\circ} \mathrm{C}$ per decade $\left(\sim+0.1^{\circ} \mathrm{C}\right.$ per decade) when calculation is performed with annual mean temperature.

In the LS, two distinct series are visible in the monthly mean temperature time

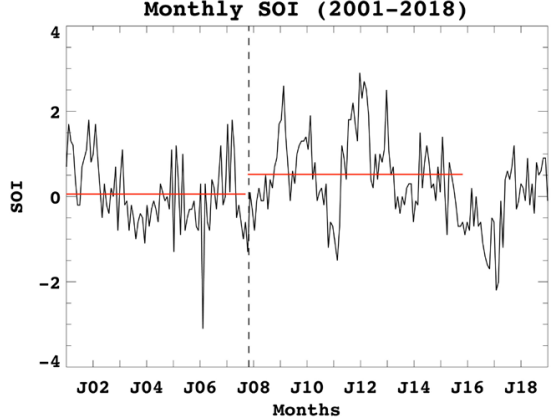

(a)

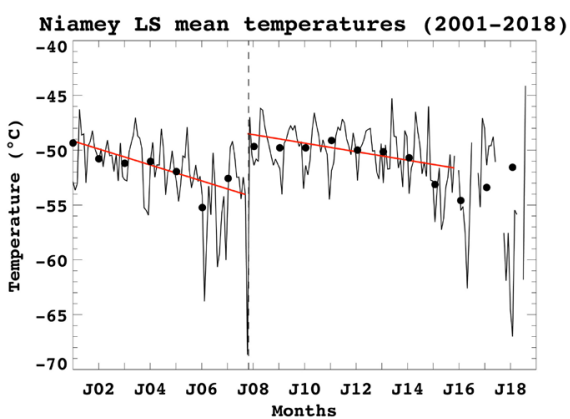

(c)

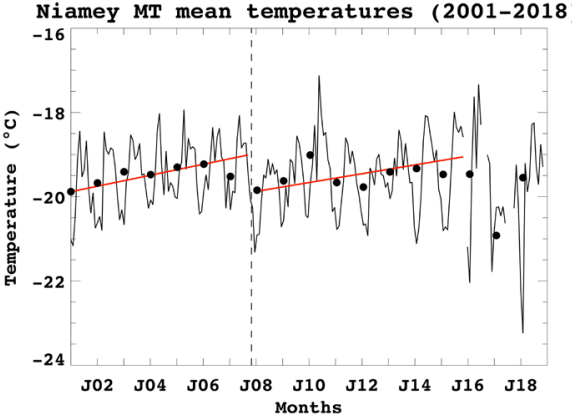

(b)

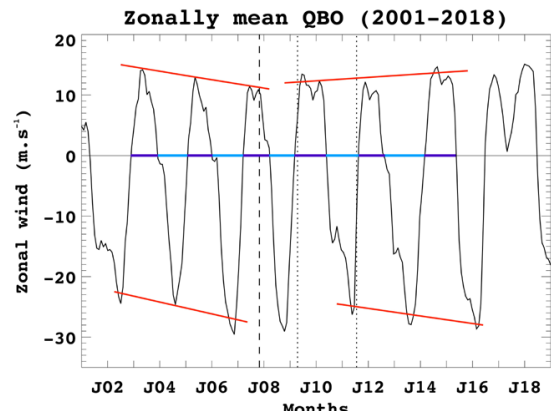

(d)

Figure 6. Time series from January 2001 to December 2018 of monthly mean above Niamey: (a) SOI; (b) Mid-troposphere temperature above Niamey; (c) Lower stratosphere temperature above Niamey and (d) Zonal wind zonally averaged in the lower stratosphere (QBO). Red lines represent the mean for SOI and the trend for the other data; Black circles represent the annual mean. The dashed line indicates the breaking point relative to SOI and temperatures series and the two dotted lines (in (d)) indicate the two breaking points of the QBO series. The dark blue and light blue lines materialize the duration of QBO W-phase and QBO E-phase respectively. 
series (Figure 6(c)) separated by the change-point observed in mid-tropospheric temperature and SOI data. Trends obtained from the linear regression are $-7.2^{\circ} \mathrm{C}$ per decade and $-3.6^{\circ} \mathrm{C}$ per decade for the first and the second series respectively. The cooling rate becomes $-0.49^{\circ} \mathrm{C}$ per decade when using annual mean values.

Perturbations observed in the oceans cause changes in several parameters such as precipitations, temperatures, wind, ... Our study focusing on parameters far from the surface, we will look at variations that ENSO could induce on the QBO. For this purpose, long-term variation of LS zonal wind is drawn in Figure 6(d). Two breaking points are detected for the QBO series located respectively in late 2007 and in early 2009. For the rest of the study, we will consider the two intervals determined from the change-point located around 2008. The first interval is observed from 2002 to the end of 2007 during the neutral phase of ENSO and the second one occurred from the end of 2008 to the end of 2015 during La Niña event. As expected, amplitude of easterlies is about twice stronger than westerlies one for the neutral phase as well as for La Niña phase. Westerlies intensity is decreasing from the beginning to the end of the neutral phase (from $+14 \mathrm{~m} \cdot \mathrm{s}^{-1}$ to $+10 \mathrm{~m} \cdot \mathrm{s}^{-1}$ ) while easterlies intensity is increasing (from -24 $\mathrm{m} \cdot \mathrm{s}^{-1}$ to $-30 \mathrm{~m} \cdot \mathrm{s}^{-1}$ ). Comparison with La Niña phase shows that westerlies and easterlies intensity are both increasing (from $+13 \mathrm{~m} \cdot \mathrm{s}^{-1}$ to $+16.5 \mathrm{~m} \cdot \mathrm{s}^{-1}$ and from $-26 \mathrm{~m} \cdot \mathrm{s}^{-1}$ to $-29 \mathrm{~m} \cdot \mathrm{s}^{-1}$ respectively). The duration of the QBO E-phase (descending easterly wind or negatif wind shear) and the $\mathrm{W}$-phase (descending westerly wind or positif wind shear) are a slight lower during neutral phase (14 and 12 months respectively) in comparison to La nina phase (18 and 14 months respectively) leading to a QBO period of about 26 and 30 months during the neutral and La Nina phase respectively.

The long-term variation of MT and LS monthly mean temperature above Niamey is similar to what is observed above Ouagadougou $\left(12.35^{\circ} \mathrm{N} ; 1.51^{\circ} \mathrm{W}\right)$ a station distanced from about $500 \mathrm{~km}$ (Figure 3 and Figure 7(a) and Figure $7(b))$. Although trends are consistent, rates of warming and cooling are both different. Ouagadougou experienced during the entire study period a greater MT warming as well as an LS cooling in comparison with Niamey. For Ouagadougou the rates calculated from the annual mean temperatures are $+0.14^{\circ} \mathrm{C}$ and $-1.16^{\circ} \mathrm{C}$ per decade for MT and LS respectively and the values found for Niamey are $+0.1^{\circ} \mathrm{C}$ and $-0.49^{\circ} \mathrm{C}$ per decade.

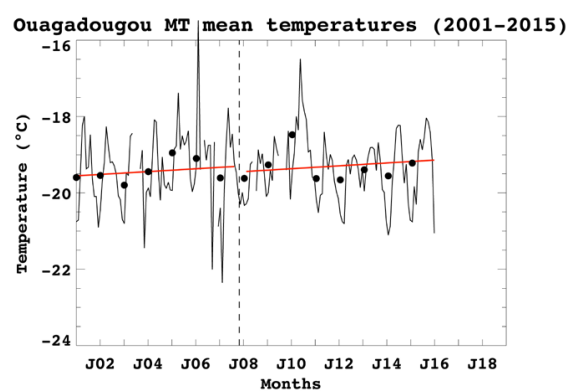

(a)

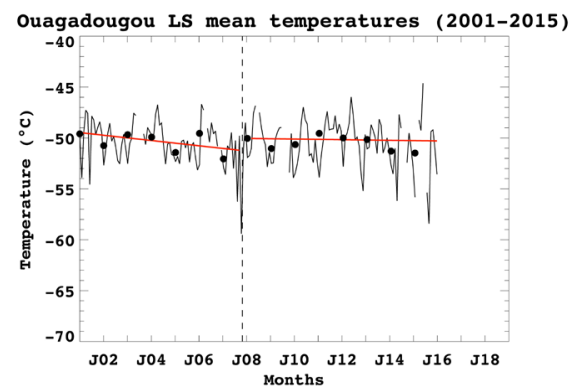

(b)

Figure 7. (a) The same as Figure 6(b); (b) The same as Figure 6(c) but for Ouagadougou. 


\section{Discussion}

The mid troposphere and lower stratosphere temperature trends found in this study are consistent with some previous results from the tropics dealing with the vertical structure of atmospheric warming.

Using RS wind data [14] and [15] highlighted an upper tropospheric warming of $0.29^{\circ} \mathrm{C}$ per decade through the thermal-wind relationship. This rate is found by [16] to be inconsistent because of three times larger than the mean of the directly measured systems. Tropospheric warming rates found in our study $\left(\sim 0.1^{\circ} \mathrm{C}\right.$ per decade) agree with their findings. The authors' study yields a warming trend of $0.65 \mathrm{~K}$ per decade below the tropical tropopause near the $200 \mathrm{hPa}$ pressure level. Later on, taking advantage of the fact that datasets become more longer and observational biases understanding more improve, [17] has analysed free atmosphere temperatures from radiosondes to compare climate model and observational dataset results. Their study was conducted for three pressure levels $500 \mathrm{hPa}, 200 \mathrm{hPa}$ and $50 \mathrm{hPa}$ (the MT, the UT and the LS respectively) and analyses were based on comparison of temperature trends. Results showed an increase of mid- and upper tropospheric temperatures and a decrease of lower stratospheric ones dominantly due to greenhouse gases and stratospheric ozone depletion respectively. They also found that the rate of mid-troposheric warming is a slight greater than what is observed in the UT.

Projections on atmospheric warming have been carried out with a lot of models and all produce a warming of the troposphere. In fact, [18] has performed comparison of atmospheric temperature trends in satellite observations and model simulations. In the tropical region $\left(20^{\circ} \mathrm{N}-20^{\circ} \mathrm{S}\right)$ spatial averages issued from five satellites observations are a quite stable and in the range $+0.1^{\circ} \mathrm{C}$ $+0.2^{\circ} \mathrm{C}$ per decade for the mid- to upper troposphere while models values are a little bit greater (around $+0.35^{\circ} \mathrm{C}$ per decade). Tropical LS cooling is subject to fluctuations $\left(-0.25^{\circ} \mathrm{C}\right.$ to $-0.4^{\circ} \mathrm{C}$ per decade) in comparison to values of the near-global domain $\left(82.5^{\circ} \mathrm{N}-82.5^{\circ} \mathrm{S}\right)$. Our results $\left(-0.49^{\circ} \mathrm{C}\right.$ and $-1.16^{\circ} \mathrm{C}$ per decade for Niamey and Ouagadougou respectively) are greater than these values. For LS, amplitudes of cooling produced by models simulations are underestimated in comparison with observations.

Thus, some differences appear in the warming rate determined from observations and models [18] and these discrepancies could be attributed to several causes such as the type of observations (radiosonde or satellites), the observation measure (sometimes tropospheric temperature estimates from satellites overlap with part of the stratosphere [19]), the length of the data series [20], estimates of temperature trends, model parameterizations (i.e. parameterization of sources such as anthropogenic effects, ocean feedbacks on a global scale, convection, radiation or clouds, ...) [20].

The Earth climate variability is related to many types of global variability (natural and/or anthropogenic). The variability of ocean temperatures represents one of the natural modes and the ENSO phenomenon (with its two components El Niño and La Niña) is among the most important. 


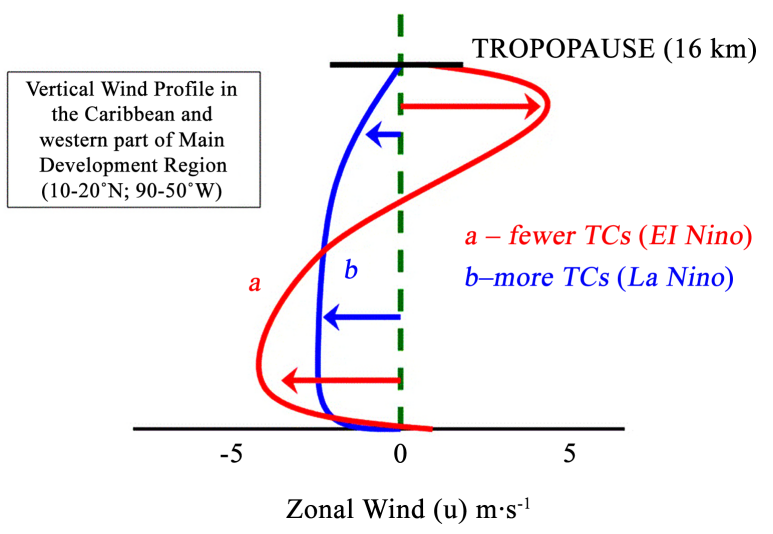

Figure 8. Changes in wind direction with height in the atmosphere in the Caribbean and western tropical Atlantic associated with El Niño (fewer hurricanes) and La Niña (more hurricanes). (Source:

https://theconversation.com/scientists-at-work-forecasting-the-atlantic-hurricane-season-77 $\underline{232)}$

At the beginning of studies discussing the relation between ENSO and West Africa Monsoon (WAM) controversial results have been found. [21] and [22] found an absence of ENSO signal in the Sahel rainfall while [23] and [24] pointed out that a warm ENSO event is associated with Sahel rainfall deficit and [25] found that La Niña's influence tends to be exactly opposite that of El Niño.

[26] has shown the impacts of ENSO phases on tropical cyclones (TC) in the Atlantic basin with a reduced activity during El Niño and an increased one during La Niña. During El Niño events upper levels of the atmosphere warmed increasing the stability of the tropical Atlantic while during La Niña events atmosphere upper-levels became colder, reducing stability and increasing thunderstorm development (Figure 8).

Our analyses of the lower stratosphere zonal wind zonally averaged have revealed that QBO characteristics are different during the neutral and La Niña phases with intensity and period both greater during La Niña event. Gravity waves (GW) have been recognized to play an important role in driving the QBO and [27] showed that tropospheric convection is a major source of GWs observed in the troposphere during the WAM. In their studies on characteristics of TC related to GWs and on link between GW activity and TC activity in the UT/LS, [28] [29] and [30] revealed strong contribution to background wind in the MT and UT as well as to the stratospheric QBO.

\section{Conclusions}

In summary, this study examined monthly mean temperature using radiosonde data from January 2001 to December 2018 in the troposphere and lower stratosphere of Niamey $\left(13.47^{\circ} \mathrm{N} ; 2.16^{\circ} \mathrm{E}\right)$ in the West Africa region. Temperature analyses performed relating to ENSO events revealed a tropospheric warming and a stratospheric cooling during the neutral and La Nina event. Zonal wind zonally averaged examination showed a stronger amplitude and a longer period 
of the QBO during La Niña event. For Niamey and the closer site Ouagadougou, the warming rates are improved when performing computation with annual mean values and tend to be consistent with the literature.

Further studies could extend the analysis to longer time period including at least one complete ENSO oscillation (i.e. El Niño event followed by La Niña event) and/or extend the area of study to the entire Sahel region to explore the vertical profile of atmosphere temperature relating to specific geographical and meteorological characteristics of stations in this area.

\section{Acknowledgements}

The authors acknowledge sincerely International Science Program (ISP) from the Swedish Cooperation which supports the BUF 01 research group, for financially supporting this publication and thank the Wyoming University and the NOAA for providing radiosonde observations, SOI and QBO data. They also thank Dr Fabrice Chane-Ming from La Reunion University for his interest in the subject and his advice.

\section{Conflicts of Interest}

The authors declare no conflicts of interest regarding the publication of this paper.

\section{References}

[1] IPCC (2001) Climate Change 2001: The Scientific Basis. Cambridge University Press, Cambridge, Chapter 2, 122-123.

[2] Stocker, T.F., Qin, D., Plattner, G.-K., Tignor, M., Allen, S.K., Boschung, J., Nauels, A., Xia, Y., Bex, V. and Midgley, P.M. (2013) IPCC, 2013: Summary for Policymakers. In: Climate Change 2013: The Physical Science Basis.Contribution of Working Group I to the FifthAssessment Report of the Intergovernmental Panel on Climate Change. Eds. CambridgeUniversityPress, Cambridge, United Kingdom and New York, NY, USA, 3-29.

https://www.ipcc.ch/site/assets/uploads/2018/02/WG1AR5_SPM_FINAL.pdf

[3] Boubacar, G., Saley, M.M., Saley, I.A., Mouhaimouni, M. and Fodé, M. (2020) Analyses statistiques des variations des températures et précipitations observées à Niamey et à Nguigmi. La Météorologie, 110, 28-33. https://doi.org/10.37053/lameteorologie-2020-0069

[4] Fontaine, B., Roucou, P., Camara, M., Vigaud, N., Konaré, A., Sanda, S.I., Diedhiou, A. and Janicot, S. (2012) Variabilité pluviométrique, changement climatique et régionalisation en région de mousson africaine. La Météorologie, numéro spécial AMMA, 41-48. https://doi.org/10.4267/2042/48131

[5] Salack S., Cornelia, K., Giannini, A., Sarr, B., Omonlola, N.W., Nouhoun, B., Bliefernicht, J. and Kunstmann, H. (2016) Global Warming Induced Hybrid Rainy Seasons in the Sahel. Environmental Research Letters, 11, Article ID: 104008. https://doi.org/10.1088/1748-9326/11/10/104008

[6] Kouassi, A.M., Kouame, K.F., Koffi, Y.B., Dje, K.B., Paturel, J.E. and Oulare, S. (2008) Analysis of Climate Variability and of Its Influences on Seasonal Rainfall Regimes in West Africa: Case of the N'zi (Bandama) Watershed in Ivory Coast. 
https://journals.openedition.org/cybergeo/23388

[7] Assemian, E.A., Kouame, F.K., Djagoua, E.V., Affian, K., Jourda, J., Adja, M., Lasm, T. and Biemi, J. (2013) Étude de l'impact des variabilités climatiques sur les ressources hydriques d'un milieu tropical humide: Cas du département de Bongouanou (Est de la Côte d'ivoire). Journal of Water Science, 26, 247-261. https://doi.org/10.7202/1018789ar

[8] Hoscilo, A., Balzter, H., Bartholomé, E., Boschetti, M., Brivio, P.A., Brink, A. and Pekelc, J.F. (2014) A Conceptual Model for Assessing Rainfall and Vegetation Trends in Sub-Saharan Africa from Satellite Data. International Journal of Climatology, 35, 3582-3592. https://doi.org/10.1002/joc.4231

[9] IPCC (2007) Climate Change 2007: The Physical Science Basis. Contribution of Working Group I to the Fourth Assessment Report of the Intergovernmental Panel on Climate Change. Cambridge University Press, Cambridge.

[10] Flato, G., Marotzke, J., Abiodun, B., Braconnot, P., Chou, S.C., Collins, W., Cox, P., Driouech, F., Emori, S., Eyring, V., Forest, C., Gleckler, P., Guilyardi, E., Jakob, C., Kattsov, V., Reason, C. and Rummukainen, M. (2013) Evaluation of Climate Models. In: Stocker, T.F., Qin, D., Plattner, G.-K., Tignor, M., Allen, S.K., Boschung, J., Nauels, A., Xia, Y., Bex, V. and Midgley, P.M., Eds., Climate Change 2013: The Physical Science Basis. Contribution of Working Group I to the Fifth Assessment Report of the Intergovernmental Panel on Climate Change, Cambridge University Press, Cambridge, New York, Chapter 9, 741-866.

https://www.ipcc.ch/site/assets/uploads/2018/02/WG1AR5_Chapter09_FINAL.pdf

[11] Ropelewski, C.F. and Halpert, M.F. (1987) Global and Regional Scale Precipitations Associated with El Nino/Southern Oscillation. Monthly Weather Review, 115, 985-996. https://doi.org/10.1175/1520-0493(1987)115<1606:GARSPP>2.0.CO;2

[12] Ropelewski, C.F. and Halpert, M.F. (1989) Precipitations Pattern Associated with the High Index Phase of the Southern Oscillation. Journal of Climate, 2, 268-284. https://doi.org/10.1175/1520-0442(1989)002<0268:PPAWTH>2.0.CO;2

[13] Thompson, D.W.J., Wallace, J.M., Jones, P.D. and Kennedy, J.J. (2009) Identifying Signatures of Natural Climate Variability in Time Series of Global-Mean Surface Temperature: Methodology and Insights. Journal of Climate, 22, 6120-6141. https://doi.org/10.1175/2009JCLI3089.1

[14] Allen, R.J. and Sherwood, S.C. (2007) Utility of Radiosonde wind Data in Representing Climatological Variations of Tropospheric Temperature and Baroclinicity in the Western Tropical Pacific. Journal of Climate, 20, 5229-5243. https://doi.org/10.1175/2007JCLI1526.1

[15] Allen, R.J. and Sherwood, S.C. (2008) Warming Maximum in the Tropical Upper Troposphere Deduced from Thermal Winds. Nature Geoscience, 1, 399-403. https://doi.org/10.1038/ngeo208

[16] Christy, J.R., Herman, B., Pielke, R.Sr., Klotzbach, P., McNider, R.T., Hnilo, J.J., Spencer, R.W., Chase, T. and Douglass, D. (2010) What Do Observational Datasets Say about Modeled Tropospheric Temperature Trends since 1979? Remote Sensing, 2, 2148-2169. https://doi.org/10.3390/rs2092148

[17] Lott, F.C., Stott, P.A., Mitchell, D.M., Christidis, N., Gillett, N.P., Haimberger, L., Perlwitz, J. and Thorne, P.W. (2013) Models versus Radiosondes in the Free Atmosphere: A New Detection and Attribution Analysis of Temperature. Journal of Geophysical Research: Atmospheres, 118, 2609-2619. https://doi.org/10.1002/jgrd.50255

[18] Santer, B.D., Solomon, S., Pallotta, G., Mears, C., Po-Chedley, S., Fu, Q., Wentz, F., 
Zou, C.-Z., Painter, J., Cvijanovic, I. and Bonfils, C. (2017) Comparing Tropospheric Warming in Climate Models and Satellite Data. Journal of Climate, 30, 373-392. https://doi.org/10.1175/JCLI-D-16-0333.1

[19] Fu, Q., Johanson, C.M., Warren, S.G. and Seidel, D.J. (2004) Contribution of Stratospheric Cooling to Satellite-Inferred Tropospheric Temperature Trends. Nature, 429, 55-58. https://doi.org/10.1038/nature02524

[20] Po-Chedley, S. and Fu, Q. (2012) Discrepancies in Tropical Upper Tropospheric Warming between Atmospheric Circulation Models and Satellites. Environmental Research Letters, 7, Article ID: 044018. https://doi.org/10.1088/1748-9326/7/4/044018

[21] Stockenius, T. (1981) Interannual Variation of Tropical Precipitation Pattern. Monthly Weather Review, 109, 133-1247. https://doi.org/10.1175/1520-0493(1981)109<1233:IVOTPP>2.0.CO;2

[22] Nicholson, S.E. and Kim, J. (1997) The Relationship of the El-Niño-Southern Oscillation to African Rainfall. International Journal of Climatology, 17, 117-135. https://doi.org/10.1002/(SICI)1097-0088(199702)17:2<117::AID-JOC84>3.0.CO;2O

[23] Palmer, T.N., Brankovic, C., Viterbo, P. and Miller, M.J. (1992) Modeling Interannual Variations of Summer Monsoons. Journal of Climate, 5, 399-417. https://doi.org/10.1175/1520-0442(1992)005<0399:MIVOSM>2.0.CO;2

[24] Janicot, S., Trzaska, S. and Poccard, I. (2001) Summer Sahel-ENSO Teleconnection and Decadal Time Scale SST Variations. Climate Dynamics, 18, 303-320. https://doi.org/10.1007/s003820100172

[25] Nicholson, S.E. and Selato, J.C. (2000) The Influence of La Nina on African Rainfall. International Journal of Climatology, 20, 1761-1776. https://doi.org/10.1002/1097-0088(20001130)20:14<1761::AID-JOC580>3.0.CO;2$\underline{\mathrm{W}}$

[26] Gray, W.M. (1984) Atlantic Seasonal Hurricane Frequency. Part I: El Niño and the 30 mb Quasi-Biennial Oscillation Influences. Monthly Weather Review, 112, 1649-1668. https://doi.org/10.1175/1520-0493(1984)112<1649:ASHFPI>2.0.CO;2

[27] Kafando, P., Chane-Ming, F. and Petitdidier, M. (2008) Climatology of Gravity Wave Activity during the West African Monsoon. Annals of Geophysics, 26, 4081-4089. https://doi.org/10.5194/angeo-26-4081-2008

[28] Chane-Ming, F., Roff, G., Robert, L. and Leveau, J. (2002) Gravity Wave Characteristics over Tromelin Island during the Passage of Cyclone Hudah. Geophysical Research Letters, 29, 18-1-18-4. https://doi.org/10.1029/2001GL013286

[29] Chane Ming, F., Chen, Z. and Roux, F. (2010) Analysis of Gravity-Waves Produced by Intense Tropical Cyclones. Annals of Geophysics, 28, 531-547. https://doi.org/10.5194/angeo-28-531-2010

[30] Ibrahim, C., Chane Ming, F., Barthe, C. and Kuleshov, Y. (2010) Diagnosis of Tropical Cyclone Activity through Gravity Wave Energy Density in the South West Indian Ocean. Geophysical Research Letters, 37, L09807.

https://doi.org/10.1029/2010GL042938 